\title{
Teaching Reform of Experiment about Electric Circuit Based on CDIO
}

\author{
Lï JiuYi* \\ Information and Control Engineering Academy, \\ Shenyang Jianzhu University \\ Shen Yang, China \\ e-mail: arnold0110@sina.com \\ * Corresponding Author \\ Wang Xin \\ School of Information \& Control Engineering \\ Shenyang Jianzhu University \\ Shenyang,China \\ Zhang Rui \\ School of Information \& Control Engineering \\ Shenyang Jianzhu University \\ Shenyang,China \\ Chen Nan \\ School of Information \& Control Engineering \\ Shenyang Jianzhu University \\ Shenyang, China
}

\author{
Mao Yongming \\ School of Information \& Control Engineering \\ Shenyang Jianzhu University \\ Shenyang, China \\ Liu Chunguang \\ Editorial Department of Journal \\ Shenyang Jianzhu University \\ Shenyang, China \\ Zhang Hui \\ School of Information \& Control Engineering \\ Shenyang Jianzhu University \\ Shenyang, China \\ Wang Bin \\ Northeastern University at Qinhuangdao \\ Qinhuangdao, China
}

\begin{abstract}
This paper introduces the basic concept of CDIO(conceive, design, implement, operate) engineering education mode, Pointing at and the lack of the existing problems in the teaching activities of the electric circuit experiment in colleges and universities. This paper discussed, in detail, the reform of the experimental teaching of electric circuit based on CDIO. The teaching reform method, which is based on the project design and the teaching method of various computer aided software, is proposed to train students' creative interests and innovation ability. A new performance evaluation method is proposed, which takes the mutual evaluation and self evaluation of the project members, and changed the way in which only the teacher was evaluated, Improved the leading role of students in the experiment. Practice shows that in the training of students' professional skills, team cooperation ability, engineering ability to achieve a good touch results. Practices show that the reform achieves better results in the experimental teaching of circuit.
\end{abstract}

Keywords- electric circuit; reform of teaching;engineering education; CDIO; competence education

\section{INTRODUCTION}

The rapid development of global science and technology, the engineer has proposed a new requirements, engineering education reform has become an important issue that can not be avoided. Colleges and universities should strengthen the consciousness of industrial civilization; cultivate innovative talents to strengthen the experiment and engineering practice, general education should be combined with the experimental and engineering practice ${ }^{[1]}$. The cultivation of innovative talents in the process, focused on ability. We should strengthen the humanities quality education of engineering students, and strengthen the cultivation of innovative spirit and innovative consciousness. In accordance with the needs of the global economic integration, the Massachusetts Institute of Technology and the Royal Institute of Technology and other 4 universities established the CDIO engineering education model, and set up a CDIO named international cooperation organization in 2004 formally ${ }^{[2]}$.

CDIO represents conceive, design, implement, operate. It takes the life cycle of product development and product development as the carrier, and allows students to study engineering in an active, practical, course, and pay attention to the cultivation of students' basic knowledge, personal ability, work in team and project system. ${ }^{[3]}$ As of 2015, China has 38 colleges and universities have carried out the CDIO model pilot, the graduates of these schools by social and business ${ }^{[4-9]}$.

Circuit is an important basic course of higher education engineering. In addition to the classroom teaching, the traditional teaching emphasis on the verification experiment, which seriously limits the cultivation of engineering students' ability on engineering? This paper takes the circuit experiment course as an example, discusses the reform and practice of experimental teaching based on CDIO engineering education mode, and puts forward the concrete reform measures, and in the 
automation professional, in the training of students' moral quality, professional skills, team cooperation ability, engineering system ability to achieve good teaching effect.

\section{CDIO ENGINEERING EDUCATION MODEL}

CDIO engineering education mode, which in the training mode to practice and exploration of the project design as a carrier to cultivate students' ability. Engineering project design is the essence of CDIO teaching mode. The project is divided into 3 levels according to size:(1) the project of the core curriculum and capacity requirements of the professional;(2) a group of related core courses and capacity requirements;(3) a small practical project according to the needs of a professional course. The main differences between CDIO teaching mode and the traditional training methods are: from the initial stage to the project design guide, around the project design will be related to the course of the organic link, project design throughout the whole process of professional learning, in the knowledge of learning and application form a positive interaction.

\section{TEACHING REFORM AND PRACTICE BASED ON CDIO CONCEPT}

\section{A. Problems existing in traditional experimental teaching}

Experimental course is a good platform to consolidate the theoretical knowledge, training students' practical ability and creativity, and it is an important part of science and engineering courses. At present, the content and teaching methods of digital circuit experiment in Colleges and universities are generally the following phenomena:

1) the experimental content is more emphasis on the verification experiment, the lack of the design experiment

At present, most of the experimental project to verify the core theory of knowledge based, students only need to step by step wiring and observation records the experimental phenomena. This experiment teaching mode is very difficult to cultivate students' practical ability and innovation ability.

2) teaching methods and assessment methods

The traditional teaching method is to explain the experimental principle and the main points of the experiment, the students in the teacher's guidance to complete the experiment. Teachers according to the experimental report submitted to the experimental situation, ignoring the specific process of the experiment

3) the experimental link is weak

The experimental link is only a part of the theory course. The students have only deepened the understanding of the relevant knowledge, and lack of the application of the knowledge, especially the application of it in the design of engineering systems. Some students feel that the curriculum is dull and boring.

4) lack of awareness of teamwork

The content of the verification experiment project is simple, which emphasizes the students' independent, and is not conducive to the cultivation of the sense of teamwork, and not meet the requirements of the modern enterprise. Circuit is a very practical course, and the experimental link is very important.
In this course, it is feasible, necessary and urgent to set up a design project of CDIO engineering education.

\section{B. Teaching reform ideas}

According to the curriculum syllabus, combined with professional training programs and training objectives, the main contents of the circuit teaching include circuit elements and circuit, simple circuit analysis method, circuit theorem, including operational amplifier circuit, frequency characteristics of circuit, three-phase circuit, periodic excitation of the circuit under the steady state response and two port Network, etc..These contents are practical and design "in order to let the students master the theoretical knowledge, and to improve the practical ability of engineering design, the main idea is to establish the CDIO based on the concept of teaching reform:

- Follow the CDIO to the engineering project design as the guide, the engineering ability training for the goal of the education mode, optimize the structure of the experiment, increase the design, comprehensive, innovative experimental project content. Key sections of the experiment to increase the corresponding design aspects, so that students are familiar with the design method and design process as soon as possible, for the comprehensive design of experimental projects in advance to lay the foundation. Increase the typical comprehensive design experiment project, let the students to grasp the basic principles of digital circuit, to cultivate students' engineering knowledge and engineering system.

- Enrich the teaching mode of experiment teaching, increase the computer aided design, project team cooperation, opening the project discussion and so on. Students learn PROTEL, MULTISIM and other software for circuit design and simulation, to master the use of computer skills for project design. Cultivate students' awareness of cooperation, project management, organizational skills, language skills, such as personal ability and team ability.

- To strengthen the innovation spirit and the cultivation of innovative consciousness, students can choose the comprehensive design according to their own interests, in addition to the basic indicators of the completion of the project, can be free to play their own creativity, increase the new functional design, training students' innovation ability

\section{The implementation of teaching reform}

School of Information \& Control Engineering, provides a good experimental environment and conditions for students to provide the necessary experimental equipment: Circuit experiment device, double trace digital oscilloscope, signal generator, DC power supply, and common use of the instrument. In addition, the establishment of a large component library, so that students apply for components in time to complete the design task, to ensure the smooth completion of the teaching reform.

The design of the circuit experiment course is the three level projects in the CDIO education model. Students as 
the main part complete the project design, project management, conception, design, and implementation. Teachers to guide the project, the two sides form a positive interaction. The framework for the implementation of the project design is shown in Fig .1.
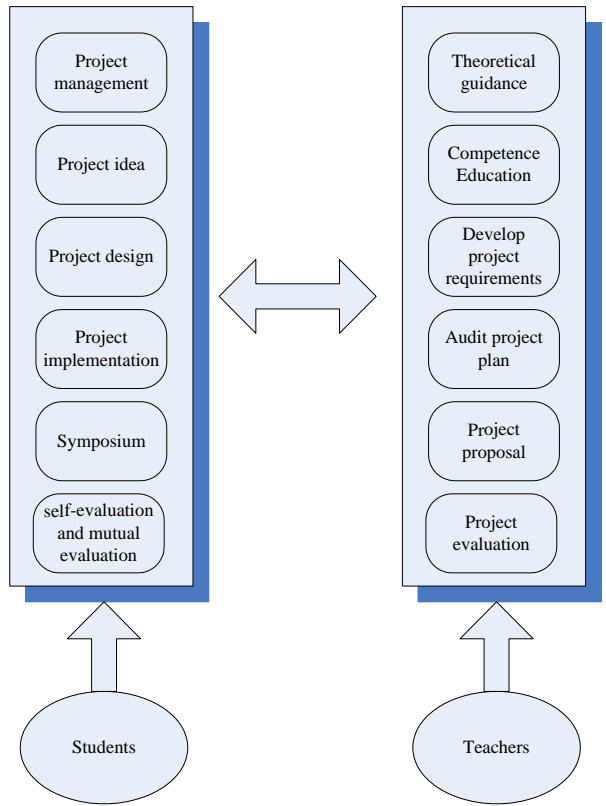

Figure 1. Project implementation framework

The general development of the project includes planning, concept development, system level design, detailed design, testing and refining, production start ${ }^{[10]}$.The following are described from various stages

- The main stage of the project is to plan and concept development. The students choose different projects in the form of team cooperation, define the design requirements of the project, analyze the project, set up targets, discuss and analyze the various solutions, and carry out the cost budget, choose the best design plan, plan the project, make the project task, project design schedule.

- In addition to the basic requirements of the basic requirements, students can put forward their views, increase the new project. Cultivate students' team cooperation ability, engineering system and independent innovation ability.

- Design stage is a detailed design of system level design and system. System level design mainly refers to the description of the various functional modules and the important interaction between the modules.

- The detailed design of the system includes: the choice of components, circuit design, circuit simulation and system performance analysis and optimization. Using electronic circuit design software PROTEL to design the circuit diagram, and use MULTISIM and other simulation software to simulate the system reliability analysis and optimization of the students' circuit design, simulation analysis and other engineering foundation knowledge and project design ability.
- In the realization stage, the students are in the actual circuit debugging and testing. Students should master the use and operation of the relevant equipment, the use of the oscilloscope and other equipment for functional and performance testing, adjust the relevant parameters of the circuit system, until the project design requirements of the indicators.

- After debugging, the circuit system demonstration and project acceptance. Each project member demonstrates and describes the project design, to show the design results, so that the students learn from each other, learn from each other, mutual evaluation. Carry out the project discussion, exchange and discuss the project design and technical difficulties, to adopt the method of self evaluation and mutual evaluation, that is, the evaluation of the project members, project members self evaluation, breaking the previous only by the teacher evaluation.

- The achievement of the project is included in the total score of the course. Enrich the teaching method, and cultivate the students' language skills. After the acceptance of the project, the project design technical report is required to develop the ability of writing technical documents.

- The contents of the report include: project objectives, design scheme, circuit and work principle, simulation results analysis, project cost accounting, work arrangement, design innovation, design process, the main problems and solutions, etc. Cultivate the students' writing ability.

Through the three levels of project design, design, implementation and operation, let the students grasp the basic knowledge of the relevant engineering, and cultivate the students' personal ability, team ability and engineering system capabilities, to meet the requirements of the CDIO mode of training

\section{THE EFFECT OF TEACHING REFORM}

Based on CDIO to engineering project design as the guidance of engineering education idea, adjust and optimize the experimental structure and experimental content, teaching methods and teaching ideas have also been optimized and innovation, enrich the experimental teaching form. The experimental teaching reform of the circuit is shown in Table 1.

TABLE I. COMPARISON OF EXPERIMENTAL TEACHING OF CIRCUIT BEFORE AND AFTER THE REFORM OF CDIO TEACHING REFORM

\begin{tabular}{|l|l|c|}
\hline & \multicolumn{1}{|c|}{ Before reform } & After the reform \\
\hline $\begin{array}{l}\text { Experiment } \\
\text { content }\end{array}$ & $\begin{array}{l}\text { Only a validation } \\
\text { experiment project is } \\
\text { opened }\end{array}$ & $\begin{array}{c}\text { New comprehensive design } \\
\text { project. }\end{array}$ \\
\hline $\begin{array}{l}\text { Experimental } \\
\text { requirements }\end{array}$ & Simple verification & $\begin{array}{l}\text { Develop project tasks, use } \\
\text { electronic design software to } \\
\text { draw the circuit diagram, } \\
\text { Simulation, build the circuit, } \\
\text { calculate and design the } \\
\text { project cost }\end{array}$ \\
\hline $\begin{array}{l}\text { Assessment } \\
\text { method }\end{array}$ & $\begin{array}{l}\text { Submit experiment } \\
\text { report }\end{array}$ & $\begin{array}{l}\text { Self evaluation was used to } \\
\text { evaluate the evaluation of } \\
\text { each other }\end{array}$ \\
\hline $\begin{array}{l}\text { Teaching } \\
\text { method }\end{array}$ & $\begin{array}{l}\text { Teaching knowledge } \\
\text { points }\end{array}$ & $\begin{array}{c}\text { Student project design } \\
\text { demonstration }\end{array}$ \\
\hline
\end{tabular}




\begin{tabular}{|l|l|c|}
\hline & \multicolumn{1}{|c|}{ Before reform } & After the reform \\
\hline $\begin{array}{l}\text { Ability } \\
\text { training }\end{array}$ & $\begin{array}{l}\text { Simple practical } \\
\text { ability training }\end{array}$ & $\begin{array}{c}\text { Essential engineering basic } \\
\text { knowledge, innovative } \\
\text { thinking\% of the } \\
\text { coordination of } \\
\text { communication\% of the } \\
\text { language to express the } \\
\text { ability to write and so on. }\end{array}$ \\
\hline
\end{tabular}

As can be seen from the table, from the experimental content, the experimental requirements, teaching methods, assessment methods and ability training, etc. have done a lot of improvement. In the case of focus on discipline knowledge, more attention to the students' ability of team cooperation ability, the ability of innovation, the cultivation of the innovative ability of the students in line with the requirements of the CDIO engineering education, and also in line with the requirements of the modern enterprise. Specific reform measures in the automation of the implementation of the students show a high degree of enthusiasm, the successful completion of the project design, the corresponding ability has been improved, and achieved good teaching results.

\section{CONCLUSION}

Circuit course is an important basic course of higher education engineering discipline, which has a strong practical ability.

This paper analyzes the phenomenon of the current college circuit experiment, discusses the new model of circuit experiment teaching based on CDIO concept, from the aspects of curriculum structure, experimental content, teaching mode, assessment method, ability training and so on.

Students as engineers have the basic knowledge of engineering, coordination and communication skills, creative thinking, language expression, writing and other personal ability, project organization, design, development and implementation of engineering system capabilities, good team cooperation ability has been improved.

The new model of experimental teaching based on CDIO theory has achieved good teaching effect in practice.

The same course has a certain reference value

\section{REFERENCES}

[1] Gu P H ,Lu X H,Xiong G J,et al, "Development of design directed engineering curriculum based on CDIO famework,"World Transaction on Engineering and Technology Education,May.2006, pp. $268-269$

[2] Gu P H ,Bao N S,Kang Q L,et al, "CDIO in china".Research in Higher Education of Engineering, Mar.2012, pp. 25-27

[3] Gu P H,Shen M F,LI S P,etal, "From CDIO toEIP-CDIO:A probe into the mode of talent cultivation in Shantou University". Research in Higher Education of Engineering,Jan.2008, pp. 12-15

[4] Wang Xin, Huang Kuan, Gao Zhijun. The Primary Users' Signals Recognition Algorithm in Cognitive Radio Networks via KPCA and Random Forest[J].ICIC Express Letters,2015, 9(4):1083-1088.

[5] Ling F,Lv T S, Fan C J, "Reform of engineering practice teaching with CDIO model". Laboratory research and exploration, Oct.2010, pp. 141-142

[6] Lu H Y,Gai Y X, Xu N, "Exploration of CDIO Engineering Education model suitable for China's national conditions". Laboratory research and exploration, Jul.2011, pp. 107-108

[7] Wang Xin,Guo Lili,Ma Lina. Cooperative Spectrum Sensing Algorithm Based on Second User Selection and Random Forest Classification[J].ICIC Express Letters, Part B: Applications,2015, 6(3):845-850.

[8] Malmqvist J,Gunnatsson S,Edstrom K, "The application of CDIO standards in the evaluation of swedish engineering degree programmes". Wofld Transaction on Engineering and Technology Education, Feb.2006, pp. 362-363

[9] Crawley E,Malmqvist J, "The CDIO syllabus v2.0-An updated statement of goals for engineering education". Proceedings of the 7th International CDIO Conference,Teachnical University of Denmark,Copernhagen, Jun.2011, pp. 21-22

[10] Ulrich K T,Eppinger S D,Product design and development, 7th ed.Beijing:Higher Education Press,2014,pp. 35-37 